\title{
Blockchain-Based Smart Contract: Advancing Digital Consumer Protection and Preventing Private International Law E-Commerce Cases
}

\author{
Tresnawati ${ }^{1}$; Angelina Marlina Fatmawati ${ }^{2}$ \\ ${ }^{1}$ Faculty of Law, Maranatha Christian University, \\ ${ }^{2}$ Faculty of Law, Maranatha Christian University. \\ Corresponding author's email: tresnawati@maranatha.edu
}

\begin{tabular}{l}
\hline Article Information \\
\hline Submitted: September 07, 2021 \\
Reviewed : November 19, 2021 \\
Revised : December 09, 2021 \\
Accepted : December 23, 2021 \\
Keywords : \\
blockchain; consumer protection; \\
private international law; smart \\
contract. \\
DoI: 10.20961/yustisia. \\
v10i3.54891
\end{tabular}

\begin{abstract}
Blockchain has functioned as a ledger that decentralizes controls with immutable and irreversible character and has the potential to overcome the deficiency of traditional contracts, especially in today's digital era, such as the e-commerce industry. Unfortunately, blockchain and smart contracts have not been applied widely in Indonesia, no regulation regulates explicitly the use of blockchain technology and smart contracts. This article will analyze the application of smart contracts to escalate consumer rights in e-commerce services. This research showed that the self-executory characteristic of smart contracts helps the consumer to have an equal bargaining position with businesses actors in determining the contents of the contract. In response to those curative efforts, the smart contract will be advantageous as a preventive scheme for PIL cases. The self-executory character of the smart contract will prevent many PIL cases that potentially occur. The immutable nature of blockchain records will also be helpful for any dispute settlement scheme. This might lead to the tendency that international e-commerce cases should not be prosecuted or set for an arbitration tribunal. Those international e-commerce cases might not require settlement of judicative branch and may be settled at the administrative level. Consequently, this would create a more effective and efficient settlement, both in time and money. Those advantages have made blockchain-based smart contracts will be prospective in Indonesia, in the upcoming future.
\end{abstract}

\section{Introduction}

E-commercehas gained widespread acceptance due to its convenience in transactions. For instance, it allows consumers to shop for products without traveling to a physical 
store. Furthermore, the Covid-19 pandemic accelerated the market penetration of e-commerce. Restrictions on movements have forced people to buy everything online due to the inevitability of human needs, a situation that has amplified the e-commerce market's growth. According to the Bank of Indonesia, yearly transaction volume reached $99 \%$ in the first quarter of 2021. Additionally, the total nominal increased by $52 \%$ yearon-year (https://ekbis.sindonews.com/ read/472710/39/e-commerce-Jadi-Andolandongkrak-penjualan-di-masa-pandemi-1625231223 2021 accessed on August 28, 2021). However, the escalation of e-commerce growth is not accompanied by adequate consumer protection (Loos \& Luzak, 2015). In international e-commerce transactions, there is no legal protection for consumers (Firdaus, 2020).

The development of e-commerce is attributed to various factors, including telematics convergence (Budhijanto, 2010, p. 54). Furthermore, the Indonesian regulation regarding information and technology applies principles that form the basis of the information technology and electronic transactions, which is stated in the elucidation of Article 3 of Law No.11 the Year 2008 Regarding Information and Electronic Transaction. One of the applicable principles is the freedom of choice of technology. This principle allowed the implementation of the technology related to information and electronic transactions to follow future developments (Fatmawati, 2021, p. 49). Therefore, the use of blockchain technology in e-commerce activities is possible and in line with the provisions of the applicable legislation.

This study focuses on business-to-consumer (B2C) e-commerce. 1 And the sale of goods. Since the volume of transactions increases, there is a high possibility of problems occurring. In general, various problems usually occur in digital trading activities that place consumers in a disadvantaged position due to the typical characteristic of e-commerce platforms. When the seller requires full payment from the consumer, the first scheme is unfavorable for the buyer. Though the seller's position is unfavorable in case the payment is not executed in full, shifting the whole risk to the consumer is unlikely. Different solutions have been offered to advance e-commerce consumer protection, including the mechanism of an escrow account or payment deposited in the marketplace until the goods are delivered to the consumer (the most widely utilized scheme in Indonesia).

The National Consumer Protection Agency (BPKN) and the Indonesian Consumers Foundation (YLKI) recorded only 48 or $1.35 \%$ complaints related to e-commerce in 2019. However, the number drastically increased to $23.11 \%$ in 2020 . These complaints include personal data matters, fraud, defects of delivered goods, refund processes, tracking delivery services, and cross-border transactions (YLKI, 2018). The Directorate of Cyber Crime of Criminal Investigation Agency data states that the total reported cases on e-commerce fraud reached 1617 cases. The most common type of fraud is the one perpetrated through an Instagram account (https://www.merdeka.com/ uang/

1 There are two most traditional e-commerce, including business to business (B2B) and business-to-consumer (B2C) 
bareskrim-catat-1617-kasus-penipuan-online-di-2019-terbanyak-di-instagram.html 2020 accessed on 28 August 2021). However, Instagram is not a marketplace or e-commerce platform. It is a social media platform commonly used by sellers and non-sellers. Furthermore, Indonesia has not centralized data on this e-commerce fraud. According to the Directorate General of Consumer Protection and Trade Order (Ditjen PKTN) of the Ministry of Trade, 396 of the 931 complaints in 2020 related to online shopping (https:/ / katadata.co.id/desysetyowati/digital/600aa5de3a818/marak-penipuan-online-saatkonsumen-hijrah-ke-digital-di-masa-pandemi 2020 accessed on August 28, 2021). It is worth noting the percentage of e-commerce complaints that have reached more than one-third of the total complaints. These data show that some e-commerce related cases in Indonesia are larger than reported. Moreover, Indonesian consumers easily believe in sellers without checking their credibility. This enhances the safety of e-commerce transactions and makes digital data protection more relevant. Most Indonesians lack awareness of how risky the dissemination of personal data is. However, this study is limited to digital data protection issues, an aspect that is undeniably relevant in the big data era.

Most Indonesian e-commerce platforms use a click-wrap agreement method. The contents of the agreement are determined by the platform owner as a standard contract. In this method, a transaction is made when customers indicate their consent to the terms and conditions by clicking the site's indicating approval button (Syahrin, 2020). This means that consumers are in a lower bargaining position.

Although the signed agreement gives rise to legal consequences to implement the rights and obligations of the parties, breach of the contract is still inevitable. The classic legal problem that frequently occurs is a non-performance contract by business actors where a particular amount of money has been paid, but the consumer does not receive the purchased goods. Although the rights and obligations of the parties in the transaction through the e-commerce platform have been regulated in several laws, various problems proved that the existing method used in the digital contract has not effectively guaranteed the protection of consumer rights.

Consumers' position is potentially infringed by having an escrow account managed by a third party or depositing the payment to the marketplace/platform owner. This is because the payment is shifted to the third party, which holds a favorable position. In some cases, the payment is not temporarily withheld or fully inexecutable, though all terms and conditions might be satisfied. This infringement cannot happen in the case of a system that is self-executable and more efficient, making the third-party unnecessary and irrelevant. The new system is a blockchain-based smart contract. However, it is wrong to imagine that a smart contract is the same as a traditional written contract with clauses full of terms and conditions because the smart contract is based on an algorithm.

The advanced blockchain technology underlying smart contracts could help resolve the problems in the e-commerce platform to promote the protection of consumer rights. 
This study aimed to examine the fundamentals of blockchain-based smart contracts function, including what they are, their relevance to consumers and merchants in the industry, and how it may prevent cases related to private international law through a conceptual research method. According to the theory of legal certainty, legal enforcement should be in line with legal norms. By applying the theory of legal certainty, this paper analyzes the questions regarding strengthening consumer rights through technology and the potential solutions.

\section{Research Result and Discussion}

\section{A. Consumer Rights Protection in Indonesia's E-Commerce Industry}

The increase in online transactions in the e-commerce business industry has significantly influenced the Indonesian internet economy. According to recent statistics, it is expected to reach USD 130 billion by 2025. Although transactions through e-commerce platforms seem alluring for convenience, accessibility, and relatively cheaper, there are risks involved. For instance, the absence of physical interaction between the seller and the buyer means the products are purchased only through visual observation of the images. To prevent inappropriate use of the advantages of e-commerce business by irresponsible business actors, consumer protection should be promoted. The seller's and the buyer's transparency indicates good faith in the e-commerce sector and involves providing specific details and descriptions of the goods purchased.

This is also a consumer guaranteed rights regulated in Law Number 8 of 1999 on Consumer Protection (UUPK). Article 1 of UUPK defines consumer protection as "all assuring legal certainty in terms of protection of consumer rights." In UUPK, there are four basic concepts of consumer protection that consist of product safety, including entrepreneur behavior, advertising procedures, the establishment of the Consumer Protection Agency, and dispute resolution. According to Article 3(c) of UUPK, consumers have the right to security and safety and the right to information, vote, be heard, compensated, and have a clean environment.

Law No. 19 of the Year 2016 on Electronic Information and Transaction (UU ITE) governs most aspects of electronic transactions. According to Article 1(2), electronic transactions are legal actions carried out through computers and their networks and other electronic media. Article 9 of the UU ITE established the obligation of business actors who provide goods through electronic systems to offer reliable information regarding the contract's terms, maker, and supplied products. This provision also applies to electronic transactions conducted on an e-commerce platform. Furthermore, some principles must be adhered to by e-commerce businesses that underlie the use of information technology for electronic transactions or other uses. The principles consist of legal certainty, 
the principle of benefit, precautionary principle, good faith, and the freedom of choice of technology according to Article 3 of Law Number 11 of 2008.

Transactions in the e-commerce platform focused on electronic contracts that bind the parties (Zein, 2009, p. 32). To fulfill the principle of legal certainty, the contracts shall meet the four requirements of a valid contract based on Article 1320 of the Civil Code of Indonesia. Subsequently, Article 46(2) of the Government Regulation No.71 of 2019 on System of Operation and Electronic Transactions regulated on the legality of an electronic contract, including (1) establishment of consent among the parties, (2) performed by competent legal subject or authorized to represent based on prevailing laws (legal capacity to contract), (3) must be on a specific subject and object matter, and (4) the object of the transaction should be in line with applicable laws and regulations. Article 70(1) Government Regulation No.71 of 2019 governing System of Operation and Electronic Transaction also requires that the contract be written in Indonesia.

In a business-to-consumer e-commerce contract, it is vital to guarantee the fulfillment of consumer rights. There are several problems regarding consumer rights in e-commerce transactions (Barkatullah, 2006, p. 35), including:

a. Consumers cannot directly identify, see or touch the goods to be ordered.

b. Unclear information about the products offered and non-existent certainty on whether consumers have obtained appropriate information is known or is required to make a decision in a transaction.

c. The unclear status of the legal subject of the business actor.

d. There is no guarantee of transaction security and privacy and an explanation of risks related to the system used, especially in electronic payments, such as credit cards or electronic currency.

e. Imposition of unbalanced risk, specifically in the event that the payment has been paid in advance, while the goods have not been received or will follow later because the existing guarantee is a guarantee of delivery of goods, not receipt of goods; and

f. Cross-border (borderless) transactions raise the issue of which country's legal jurisdiction applies.

Problems concerning electronic transactions are frequently caused by basic contract issues, including the contract terms, such as the offer, acceptance, consideration, and validity of the agreement, and cases of errors and their consequences, incorrect statements, and coercion (Elwina, 2013). For consumers, information about goods and services marketed on e-commerce services is a basic need in transacting with business actors on e-commerce services (Article 47(3) Government Regulation Number 71 of 2019 Concerning System of Operation and Electronic Transaction, n.d.). It has also evolved into business actors' responsibilities to consumers (Article 9, Article 12 Law Number 11 the Year 2008 Concerning Electronic Information and Transaction, n.d.). 


\section{B. Characteristic of Blockchain-Based Smart Contract}

Nick Szabo, a computer scientist, and cryptography expert introduced the term "smart contract" in 1994, described as "...a computerized transaction process that carries out a contract's terms" (http://www.fon.hum.uva.nl/rob/ Courses/InformationInSpeech/CDROM/Literature/LOTwinterschool2006/ szabo.best.vwh.net/smart.contracts.html 1994 accessed on August 24, 2021). In the smart contract system, Nick Szabo uses blockchain or ledger (decentralized ledger). The underlying algorithm in blockchain technology utilizes a consensus mechanism that acts as 'negotiators' before a contract is formed, allowing the parties to arrange and choose the order terms for the counterparty (Scholz, 2017). Furthermore, the counterparty can send the proposed terms of a contract to another party, constituting a counter offer.

Smart contracts are "digital contracts that allow terms contingent on decentralized consensus and are self-enforcing and tamper-proof through automated execution" (Cong et al., 2018, pp. 11-12). In another way, a smart contract also could be defined as "an agreement between two or more parties that is encoded in such a way that blockchain ensures correct execution". The mechanism of a vending machine is a basic explanation for how smart contracts work. It simply executes the contract by dispensing the paid products. The chosen product is obtained after selecting and paying for it. Classic problems for vending machines occur when the dispensed product is jammed in the machine. However, this problem merely occurred in the early stages of vending machines production. This kind of improvement also applies to blockchain-based smart contracts from time to time.

Blockchain comprises groups of entries of records of multiple transactions collected into a 'block' (Yaga et al., 2018). Each entry block has a cryptographic hash that connects it to the rest of the blockchain. These entries will be stored as a 'ledger' to be distributed and disseminated through numerous computers without a central repository. The entered record is immutable, or if altered, the alteration will be detected, both through the cryptography used and from the disseminated nature of the ledger (Rosic, 2020). This means that anything recorded in the blockchain will stay there forever, and no one can change it without the rest of the system knowing. This gives the system its trustworthiness, credibility, and dependability.

By utilizing blockchain technology, all information in the platform system could be brought into a trusted environment accessed by all parties in the platform. Related parties can access all documentation regarding the transaction conducted on the platform. Furthermore, all the data could be determined with certainty (Alliance, 2018, p. 39). In case all appropriate conditions in the contract have been met, the ledger is served as the basis for executing the contract and 
issuing final approval before executing the contract without human intervention (Alliance, 2018, p. 39). Blockchain would lessen potential disputes between the parties, leading to a more efficient economy. Disputes may be resolved at the administrative level, reducing the burden of numerous litigation and nonlitigation institution cases.

\section{Application of Blockchain-Based Smart Contract}

The blockchain-based smart contract applies to different cases in various fields, including the financial sector, government sector, health and sciences, and e-commerce (Ream. et al., 2016). Smart contracts based on the blockchain have been widely used in e-commerce. For example, IBM and Maersk announced the completion of an end-to-end digitalized supply chain pilot utilizing blockchain technology in 2017, which included trade parties and multiple ports and customs authorities in collaboration with Hyperledger Fabric (Allison., 2017). As a result, a digital company in Singapore, Qoo10, applied the blockchainbased smart contract in their e-commerce platform, QuuBe. This contract is one of the greatest e-marketplaces in Asia (https://www.quube.xyz/gmkt.inc/ Company/About Company. aspx 2020 accessed on August 23, 2021).

Another example of a blockchain-based smart contracts application is in the fuel and oil sales platform, 'Gazpromneft Aero,' released in 2018. The platform is managed by S7 Airlines and Alfa-Bank with Gazpromneft Aero in Belarus. Although blockchain-based smart contract exists, it has not been widely regulated in law. Belarus officially regulates blockchain-based smart contracts in their national law (Decree of the President of the Republic of Belarus No. 8 of December 21, 2017, n.d.).

The e-commerce growth is attributed to telematics convergence (Budhijanto, 2010 , p. 54). Indonesia's regulation on information and technology also applies principles that form the basis of information technology and electronic transactions. The regulation is stated in the elucidation of Article 3 of Law No.11 the Year 2008 Regarding Information and Electronic Transaction. One of the applicable principles is the freedom of technology choice. This principle allowed the implementation of the technology related to information and electronic transactions to follow future developments (Fatmawati, 2021, p. 49). Consequently, the use of blockchain technology in e-commerce activities is possible and in line with the provisions of the applicable legislation.

\section{Blockchain-Based Technology According to Regulation of Bank Indonesia}

Although smart contracts are yet to be discovered in Indonesia, the country has already acknowledged the benefits of blockchain technology. The Regulation of Bank Indonesia No. 19/12/PBI/2017 on Financial Technology Management 
states that "blockchain as a form of implementing financial technology in the payment system that functions to carry out authorization, clearing, final settlement, and payment settlement." The application of blockchain technology on a cryptocurrency platform is further regulated in the Commodity Futures Trading Supervisory Agency (BAPPEBTI) Regulation Number 5 of 2019 Concerning Technical Provisions for the Implementation of the Physical Crypto Asset Market on the Futures Exchange.

The legal basis for blockchain technology in Indonesia is still limited to the financial sector. As previously stated, blockchain regulation can be inevitable in cryptocurrency as applicable law, e-commerce platforms, and other important fields. Blockchain is part of the future.

\section{E. Characteristics of Transaction in Current E-Commerce Platform}

Most transactions in the e-commerce platform are executed using an online agreement known as a "click-wrap agreement" (Wardani \& Afriansyah, 2020). The term 'click-wrap' is used because the consumer accepts the contents of the agreement by typing 'I Agree' or just mouse-clicking an 'I Accept' or equivalent button/icon (Fitzgerald, 2011, pp. 754-756). As a result, click-wrap agreements are formed differently and are classified as conventional contracts. There is no opportunity for consumers to negotiate the contents of the contract/agreement. This puts consumers at a low bargaining position in the transactions. No physical contracts or signatures are needed to bind consumers to the agreements. Trust is the only means indicating that the other party will behave as expected in the existing contract (Gefen, 2000).

Indonesian e-commerce platforms mainly use the click-wrap mechanism to create binding transactions with consumers. Most of them present agreements regarding terms and conditions related to the use of the platform as 'take it or leave it in a standardized contract (Johansson, 2014). There is no involvement of the other party to make rebuttals, addition, or correction towards the contract clause, whether at the pre-contractual stage or during contract execution.

Standardized contracts often narrow the principles between parties. The only remaining freedoms include entering the contract and choosing its opposites. The disadvantaged party in its bargaining position on a standardized contract is the consumer.

E-commerce platform owners may not directly deal with consumers, meaning that they act as intermediaries between sellers and consumers. These platforms include Tokopedia, Bukalapak, Shopee, Lazada, Alibaba, and OLX, among others. Furthermore, e-commerce platforms also apply an exoneration clause that limits the liability of the platform owners towards any claim of the consumers in case the transaction between the consumer, and the seller is not properly implemented as specified in the agreement (Hernoko, 2008, p. 95). 
The products are expected to be displayed virtually on the platform by the sellers. Prospective consumers interested in the offered products may process further payment. The product is delivered through a delivery service after the payment has been completed (Ahmadi \& Yodo, 2008, p. 38). In general, there are four main stages of the whole transaction process, 1) an offer, where the vendor sells their goods via an e-commerce site, 2) acceptance, where further transactions occur after the consumer decides to accept the offer, 3) the payment process with different methods, including cash on delivery (COD), transfer, credit card, and virtual money, and 4) delivery of the product, mainly through delivery services provider as the third party, such as TIKI, JNE, and others.

This mechanism puts the whole transaction process into four stages that stand independently. Different parties are involved in different mechanisms, each with distinct responsibilities. In the four stages, all parties usually apply the exoneration clause not to be held responsible for any other party's fault. There is a default risk because the transaction stages are not party linked to each party directly. The consumer may become the weakest party in the current mechanism applied in the e-commerce industry. Therefore, the government shall ensure a decent standard of consumer protection in their enacted regulations because most Indonesians are consumers, though more parties are involved in e-commerce contracts.

Some cases show how weak the protection of consumer rights is in existing e-commerce transactions. For example, on June 06, 2016, a consumer named Anthony purchased a watch for Rp.69,000 through the platform. He made payment via Automated Teller Machine (ATM) to Lazada. co.id Virtual account with order number 384328958 on the same day at 20:28. The product was not received between July 30 and August 06. On June 07, Anthony checked the order and was informed that it had been verified and put in the delivery process starting in the next 3 working days. On June 14, 2016, Lazada informed that the order was already delivered from Hong Kong via China post courier with estimated delivery of 35 days and receipt number RG286735510CN.

On July 22, 2016, at 11:26 WIB, Lazada reported that the system had canceled the order. At 14:15, Lazada confirmed the refund account number 38432895 and asked to fill out a refund form, yet there was no reply until July 24 . After being contacted, Lazada said that payment was not found and asked for proof of account mutation from the transaction date to the next 7 days. In this case, Lazada failed to deliver on its promise, harming the customer.

Although the amount of personal loss seems insignificant, there was an injustice and inequal position between layperson, specifically the platform owner and seller. Accumulated minor problems may end up being costly. Grab Toko case involved 980 people defrauded by Grab Toko 17 billion Rupiahs 
(https:/ / www.cnnindonesia.com/ekonomi/20210115135836-92-594181/ kronologi-grab-toko-tipu-980-orang-dan-rugikan-rp17-m 2021 accessed on August 29, 2021). This issue began with Grab Toko investors' default to its management, which caused non-performance of delivery to consumers by Grab Toko management.

\section{F. Utilizing Smart Contracts in E-Commerce Transactions to Increase Consumer Protection}

The existing problems, such as Anthony's case, could be overcome by applying blockchain-based smart contracts on the e-commerce platform. The blockchain-based smart contract offers more secured transactions without changing the four stages of the transaction flow in the current e-commerce platforms. A good example is the application of fuel and oil sales platform 'Gazpromneft Aero.'

The aircraft fuel orders are stated in the form of a smart contract containing information on the cost and amount of fuel for the aircraft. The placed order can be executed after the aircraft commander makes a reservation regarding the fuel required for the flight to the operator. Refueling can be carried out when the online order is placed in line with the reservation. At the end of refueling, the amount of funds belonging to S7 Airlines at Alfa-Bank is debited, and the transaction is recorded by a department responsible for receiving information about closing the transaction with all documents. The smart contract program used by Alfa-Bank and S7 Airlines is conducted on the Hyperledger blockchain platform.

Online transactions in an e-commerce platform are centered on the mutual trust of the involved party. In case all the parties are acquainted with each other, trust can be built better because the conduct of the sales and purchase transactions interrelates. Since sellers and buyers are strangers to each other in the e-commerce transaction, prudential measures should be taken to protect each party's interest. This cautions the consumer against possible losses that may occur during the transaction. Each party shall bear a balanced bargaining position where the contracts shall contain the rights and obligations of each party.

Smart contracts based on the blockchain can make e-commerce platforms more safe, efficient, and transparent. The technology might offer a whole new model and concept that could address the shortcomings of present e-commerce platforms. Since digital commerce platforms are increasingly being used, there is a need for optimum protection to combat the high levels of fraud prevalent in the e-commerce industry. In general, blockchain-based smart contracts can provide an ideal platform and escalate digital trust in e-commerce transactions. 
Smart contracts promote the development of better consumer protection laws that can protect consumers from unauthorized or fraudulent transactions. These contracts keep the manufacturer and vendor liable for any breach of contract by the consumer. Furthermore, they could mitigate the trust issue among the parties to conclude the contract since the execution is determined by completing the required conditions in the contract execution algorithm.

Another question concern is whether these contracts are enforceable in relation to consumer behavior and e-commerce transactions within the Indonesian legal framework. Although smart contracts have been rapidly utilized, their usage in Indonesia has not been discovered (Ranto, 2019). According to the principles of utilization of information technology and electronic transactions, using information technology and electronic transactions can follow developments in the future (Fatmawati, 2021, p. 141). Moreover, the permanent and decentralized characteristics of blockchain technology make transaction contracts irreversible by one party. The decentralized blockchain verification system makes smart contracts safer than the current system used in digital contracts in Indonesia (click-wrap agreement systems).

\section{G. Smart Contract Prevents E-Commerce Related to Private International Law Cases}

PIL is a branch of national law that deals with private cases involving foreign aspects. In general, it always addresses three issues, including 1) applicable jurisdiction, 2) applicable legislation, and 3) recognition and enforcement of foreign judgments in a specific country. Indonesia has very limited resources on PIL, with regulations still originating from those that prevailed since Dutch Colonialization.

For jurisdiction issues, Indonesian legal scholars refer to Article 118 Indonesian Civil Procedural Code or Het Herziene Inlandsch Reglement (HIR) or Reglement Buitengewesten (RBg), which is based on actor sequitur forum rei principle as the basis of general jurisdiction. Article 100 of Reglement op de Rechtsvordering (RV) is also used to represent and sue foreigners in District Court. The Article stipulates that a foreign citizen, including those not domiciled in Indonesia, may be sued before the court for any obligation in Indonesia or anywhere with its citizens.

Indonesia has particular regulations on applicable laws in specific statutes. However, the general provisions are only in Article 16-18 Algemene Bepalingen van Wetgeving. Article 16 regulates personal status on nationality (lex patriae), Article 17 states immovable goods' applicable law is lex rei sitae (the law of the place where such immovables are situated). In contrast, Article 18 regulates that applicable law on legal action will be the law of the place where the act was conducted (lex loci actus). 
Concerning recognition and enforcement of the foreign judgment, any lawyer would rely on Article 436 of Reglement op de Rechtsvordering (RV). This article regulates that a foreign judgment is not applicable in Indonesia and will be submitted as prima facie evidence only, and judges will reexamine the foreign judgement by merits. Despite the fact that all of the PIL provisions described above are obsolete, they continue to be used. Ministry of Law and Human Rights and National Legal Development Agency (BPHN) are struggling for the enactment of New PIL for the third attempt. First draft and the second draft did not manage to be included in National Legislative Program. The third attempt which was initiated by the Association of Indonesian Lecturers and Observants of PIL (APPIHPI), is rolling for National Legislative Program. Yet, it might take two years more, before the new PIL is enacted.

Most sellers are interested in joining e-commerce due to its unlimited market. Its cross-border nature stimulates more e-commerce cases related to PIL. At the moment, PIL contract case settlement relies on the choice of law and court, though these choices are also not consistently executable before Indonesian courts. When such choices are not available, executable, or applicable for whatever reason, PIL prevails. However, PIL is quite ancient, making most Indonesians and foreigners avoid their applicability in the contract.

After Government Regulation on Electronic Commerce No. 80, the Year 2019 was enacted, its article 73 stipulates that "(1) The parties have the authority to choose the law applicable to the international e-commerce contracts. (2) In the event that the parties do not choose the law in international e-commerce contracts, the applicable law is based on the principles of PIL". Based on the uptrend of e-commerce in Indonesia, PIL is inevitable. However, the objective of this section is to prove that some PIL-related cases may be prevented. The Indonesian PIL cannot settle any international e-commerce cases because it still refers to Article 18 based on lex loci actus. The lex loci actus principle has been modernized in many countries, while PIL in Indonesia is stagnant.

International e-commerce cases are increasing, though the solution is delimited in dispute settlement mechanisms, such as online arbitration. However, its applicability in Indonesia has not gained popularity. In response to these curative efforts, the smart contract will be advantageous as a preventive scheme for PIL cases. The self-executory character of the smart contract prevents many PIL cases that potentially occurred. The immutable nature of blockchain records will also be helpful for any dispute settlement scheme. This might be led to the tendency that international e-commerce cases should not be litigated or set for an arbitration tribunal. The international e-commerce cases might not require the settlement of the judicial branch. They can be settled at the administrative level, such as the Ministry of Trade. This may create a more effective and efficient settlement in time and money. 


\section{Conclusion}

Consumers suffer from a high number of situations involving transactions on e-commerce platforms. Different interests might put consumers at a loss for not obtaining the optimum benefits from the goods and services purchased through the e-commerce platform. This necessitates efforts to guarantee consumer protection and balance businesses and consumers in e-commerce transactions. This legal protection will help avoid infringing certain consumer rights or fraud and unfair competition (Mantri, 2007, p. 56).

To promote consumer protection, blockchain-based smart contracts will help address the existing problems in the e-commerce industry. Due to the lower possibility for default or breach of contracts, blockchain-based smart contracts are better than the current technology used in e-commerce platforms. Furthermore, Smart Contract will help prevent e-commerce related PIL cases due to its self-executory nature. The irreversible nature of blockchain will make dispute settlement easier.

\section{Bibliography:}

Ahmadi, M., \& Yodo, S. (2008). Hukum Perlindungan Konsumen. PT RajaGrafindo Persada, Jakarta.

Alliance, S. C. (2018). Smart Contracts: Is the Law Ready? Chamber of Digital Commerce.

Allison., I. (2017). Maersk and IBM want 10 Million Shipping Containers on the Global Supply Blockchain by Year-End. International Business Time.

Barkatullah, A. H. (2006). PERLINDUNGAN HUKUM BAGI KONSUMEN DALAM TRANSAKSI E-COMMERCE LINTAS NEGARA DI INDONESIA. https:// dspace. uii.ac.id/handle/123456789/9394

Decree of the President of the Republic of Belarus No. 8 of December 21, 2017, Library of Congress, Washington, D.C. 20540 USA. https://www.loc.gov/item/globallegal-monitor/2018-01-03/ belarus-decree-introduces-common-law-principlesand-tax-exempts-mining-of-cryptocurrencies/

Budhijanto, D. (2010). Hukum telekomunikasi, Penyiaran, dan Teknologi Informasi. In Bandung, Refika Aditama. PT Refika Adhitama.

Chrisbiyanto, A. (2021). E-Commerce Jadi Andalan Dongkrak Penjualan di Masa Pandemi. In ekbis.sindonews.com. https:/ / ekbis.sindonews.com/read/472710/39/ e-commerce-jadi-andalan-dongkrak-penjualan-di-masa-pandemi-1625231223

Cong, L. W., He, Z., \& Zheng, J. (2018). Blockchain Disruption and Smart Contracts. SSRN Electronic Journal. https://doi.org/10.2139/SSRN.2985764 
Elwina, M. (2013). ASPEK HUKUM TRANSAKSI (PERDAGANGAN) MELALUI MEDIA ELEKTRONIK (E-COMMERCE) DI ERA GLOBAL: SUATU KAJIAN PERLINDUNGAN HUKUM TERHADAP KONSUMEN. Legality: Jurnal Ilmiah Hukum, 20(2). https:// ejournal.umm.ac.id/index.php/legality/article/view/278

Fatmawati, A. M. (2021). Urgensi Pengaturan Smart Contract Dalam Sistem Hukum Indonesia: Studi Terhadap Pengaturan Smart Contract di Negara Belarus.

Firdaus, D. H. (2020). Aplikasi Smart Contract dalam E-Commerce Prespektif Hukum Perjanjian Syariah. Qolamuna: Research Journals and Islamic Studies, 6(1). https:// apjii.or.id/survei,

Fitzgerald, B. F. (2011). Internet and e-commerce law, business, and policy. Thomson Reuters (Professional) Australia Ltd. http://eprints.qut.edu.au/57889/

Gefen, D. (2000). E-Commerce: The Role of Familiarity and Trust. Omega, 28(6).

Government Regulation Number 71 of 2019 concerning System of Operation and Electronic Transaction.

Hernoko, A. Y. (2008). Asas Proporsionalitas Dalam Kontrak Komersial. In Yogyakarta: Laksbang Mediatama. Laksbang Mediatama.

Indonesia, C. N. N. (2021). Kronologi Grab Toko Tipu 980 Orang dan Rugikan Rp17 M. In CNN Indonesia. https://www.cnnindonesia.com/ ekonomi/20210115135836-92-594181/ kronologi-grab-toko-tipu-980-orang-danrugikan-rp17-m

Johansson, A. (2014). A Study of United States of America Contract Law and a Survey of the Practices of Software Companies The Enforceability of Clickwrap Agreements. UMEA Universitet Journal, 3(1).

Law Number 11 the Year 2008 Concerning Electronic Information and Transaction.

Loos, M., \& Luzak, J. (2015). Wanted: a Bigger Stick. On Unfair Terms in Consumer Contracts with Online Service Providers. https:/ / doi.org/10.1007/s10603-015-9303-7

Mantri, B. H. (2007). PERLINDUNGAN HUKUM TERHADAP KONSUMEN DALAM TRANSAKSI E-COMMERCE. LAW REFORM, 3(1), 1-21. https://doi. org/10.14710/LR.V3I1.12340

Merdeka. (2020). Bareskrim Catat 1.617 Kasus Penipuan Online di 2019, Terbanyak di Instagram | merdeka.com. In Merdeka.com. https://www.merdeka.com/uang/ bareskrim-catat-1617-kasus-penipuan-online-di-2019-terbanyak-di-instagram. html 
QuuBe - Factory Wholesale by Qoo10. (2020). In QuuBe. https://www.quube.net/gmkt. inc/Company/AboutCompany.aspx

Ranto, R. (2019). TINJAUAN YURIDIS PERLINDUNGAN HUKUM TERHADAP KONSUMEN DALAM TRANSAKSIJUAL BELI MELALUI MEDIA ELEKTRONIK. Jurnal Ilmu Hukum Alethea, 2(2). https://katadata.co.id/berita/2016/02/18/ pemerintah-beberkan-kecurangan-e-

Ream., J., Chu., Y., \& Schatsky., D. (2016). Upgrading blockchains: Smart contract use cases in industry | Deloitte Insights. Deloitte Insight. https://www2.deloitte. $\mathrm{com} / \mathrm{us} / \mathrm{en}$ / insights/focus/signals-for-strategists/using-blockchain-for-smartcontracts.html

Rosic, A. (2020). What Are Smart Contracts? [Ultimate Beginner's Guide to Smart Contracts]. In blockgeeks.com. https://blockgeeks.com/guides/smart-contracts/

Scholz, L. H. (2017). Algorithmic Contracts. Stanford Technology Law Review, 20(2). https://ir.law.fsu.edu/articles/ 607

Setyowati, D. (2020). Marak Penipuan Online saat Konsumen Hijrah ke Digital di Masa Pandemi - Teknologi Katadata.co.id. In katadata.com. https://katadata.co.id/ desysetyowati/digital/600aa5de3a818/marak-penipuan-online-saat-konsumenhijrah-ke-digital-di-masa-pandemi

Syahrin, A. (2020). Konsep Keabsahan Kontrak Elektronik Berdasarkan Hukum Nasional dan UNCITRAL Model Law on Electronic Commerce. Jurnal Hukum Kenoktariatan, $6(1)$.

Szabo, N. (1994). Smart Contracts. https://www.fon.hum.uva.nl/rob/Courses/ InformationInSpeech/CDROM/Literature/LOTwinterschool2006/szabo.best. vwh.net/smart.contracts.html

Wardani, N. K., \& Afriansyah, A. (2020). Indonesian Legal Challenges Regarding Electronic Contracts in International Trade.

Yaga, D., Mell, P., Roby, N., \& Scarfone, K. (2018). Blockchain Technology Overview, Draft NISTIR 8202. https:/ / csrc.nist.gov/ publications.

YLKI. (2018). Catatan Perlindungan Konsumen 2018 (edisi 1): Ekonomi Digital dan Marginalisasi Hak Konsumen. https://ylki.or.id/2018/12/catatan-perlindungankonsumen-2018-edisi-1-ekonomi-digital-dan-marginalisasi-hak-konsumen/

Zein, Y. A. (2009). Kontrak Elektronik dan Penyelesaian Sengketa Bisnis E-Commerce dalam Transaksi Nasional dan Internasional (Indonesia. U.-U. T. I. dan T. Elektronik, Ed.). Mandar Maju. 